\title{
Effect of Saliva Contamination on Microleakage of Open Sandwich Restorations
}

\section{Učinak onečišćenja slinom na mikropropuštanje otvorenih sendvič-restauracija}

Faculty of Dentistry, Department of Restorative Dentistry, Kırıkkale University, Turkey

Odsjek za restaurativnu stomatologiju Stomatološkog fakulteta Sveučilišta Kırıkkale Yahşihan, Turska

\section{Abstract}

Objectives: The purpose of the present study was to evaluate the microleakage of conventional glassionomer, resin modified glass-ionomer and glass hybrid ionomer Class II open sandwich restorations with or without saliva contamination. Material and methods: Sixty extracted sound human molar teeth were used and 120 class II slot cavities were prepared in mesial and distal surfaces. The gingival margins were located $1 \mathrm{~mm}$ below the cementoenamel junction. All specimens were randomly divided in 4 groups ( $n=15)$ : Group I: High-Viscous Glass Ionomer (Fuji IX GP) Group II: Resin Modified Glass Ionomer (Fuji II LC) Group III: Glass Hybrid lonomer (Equia-fil Forte), Group IV: Composite Resin (G'aenial Posterior). In open sandwich restoration groups, glass ionomer materials were placed to gingival floor in $1 \mathrm{~mm}$ thickness and rest of the cavity was filled with resin composite. After the restorations in mesial surfaces had been performed, distal cavities were restored with the same protocol after saliva contamination. The specimens were thermo-cycled for 10000 cycles at $5^{\circ} \mathrm{C}$ to $55^{\circ} \mathrm{C}$ and immersed in methylene blue dye solution $(\% 0,5)$ for 24 hours. Then, they were sectioned vertically through the center of the restorations from mesial to distal surface with a water-cooled diamond saw with $1 \mathrm{~mm}$ thickness. Subsequently, the dye penetration was evaluated with image analysis software. Data were statistically analyzed $(p<0.05)$. Results: There was a statistically significant difference between gingival microleakage scores in no contamination groups, between high-viscous glass ionomer, Fuji IX GP and other materials tested $(p<0.05)$. In saliva contaminated groups, there was no statistically significant difference between gingival microleakage scores $(p>0.05)$. Additionally, there was not a statistically significant difference between the no contamination and saliva contaminated groups regardless of dental materials tested $(p>0.05)$. Conclusion: Within the limitations of this study, in open sandwich restorations, saliva contamination did not show an adverse effect on microleakage irrespective of dental materials tested. Glass hybrid ionomers and resin modified glass ionomers showed lower microleakage scores in gingival margins compared to high-viscous glass ionomer material in no contamination groups.
Received: January 30, 2020

Accepted: July 29, 2020

Address for correspondence Professor Çiğdem Çelik, PhD Kırıkkale University Faculty of Dentistry Department of Restorative Dentistry Yenişehir Mh. Çelebi Sok. No: 1 71450 Yahşihan

Kırıkkale, TURKEY

Phone: +90 3182244927

ccelik75@gmail.com

\section{Introduction}

Resin composites are the best and most used restorative materials for anterior and posterior teeth due to esthetic and mechanical properties. However, polymerization shrinkage and technique sensitivity are drawbacks of these materials. In some class II restorations, gingival margins could be located below the cementoenamel junction and marginal adaptation would be difficult to achieve (1). The open sandwich technique had been demonstrated to overcome these problems (2). According to this technique, a glass ionomer material is used to replace the dentin and also fill the cervical part of the box, which results in a part of the glass ionomer being exposed to the oral cavity (3). This technique has some limitations due to the fact that the polymerization contraction stress of resin composite might affect the bond between glass ionomer and the dentin at gingival margin in the initial stages of glass ionomer setting reaction (4-7). Also, there were
Uvod

Kompozitne smole najbolji su i najčešće korišteni restaurativni materijali za prednje i stražnje zube zbog estetskih i mehaničkih svojstava. No polimerizacijsko skupljanje i osjetljivost na proceduralne pogreške glavni su nedostatci tog materijala. U nekim restauracijama II. razreda aproksimalni rubovi mogu biti smješteni ispod caklinskocementnog spojišta i teško je osigurati adekvatnu rubnu prilagodbu (1). U rješavanju toga problema klinički se dokazala otvorena sendvič-tehnika (2). U toj se tehnici staklenoionomerni materijal upotrebljava za nadomještanje dentina i za punjenje cervikalnog dijela kaviteta, što rezultira time da je dio staklenog ionomera izložen usnoj šupljini (3). Ta tehnika ima određena ograničenja zbog činjenice da naprezanje zbog polimerizacijske kontrakcije kompozita smole može utjecati na vezu između staklenog ionomera i dentina uz rub gingive u početnim fazama reakcije stvrdnjavanja staklenog ionomera $(4-7)$. Tako- 
some concerns about adequate polymerization of resin portion of resin modified glass ionomer materials in deep cavities. Roberts et al.(8) recommended the use of conventional high powder/liquid ratio glass ionomers for cavities extending to the root surface. In previous studies, Dietrich et al.(3) and Lougercio et al.(9) showed that the use of resin modified glass ionomers for the open sandwich technique, improved the marginal adaptation of the restoration. Additionally, it was also stated that bonding of composite to resin-modified glass ionomers could not be a problem due to the HEMA content and these materials could easily adhere to the methacrylate-based resin materials, such as resin composites (10).

In the last decade, a hybrid glass ionomer material, Equia-fil Forte (GC, USA), has been introduced to the dental market. Equia-fil Forte was produced by dispersed ultrafine and highly reactive glass particles. The molecular weight of the polyacrylic acid was optimized to give the material excellent mechanical strength and properties. There were numerous studies which evaluated the in vitro and in vivo performance of this glass hybrid ionomer system and successful results were obtained (11-15).

However, there is no consensus about techniques to minimize microleakage in gingival margins located on dentin in the dental literature. There is also a lack of information about highly viscous glass ionomers, used as a base material in open sandwich restorations and the presence of saliva contamination. Therefore, the aims of the present study are as follows:

1. To evaluate microleakage scores in gingival margin below the cemento-enamel junction in Class II open sandwich restorations using three different glass ionomer materials and to compare them with a resin composite group;

2. To examine the effect of saliva contamination in microleakage scores of all groups tested.

The null hypothesis of the study was that a glass ionomer material type and saliva contamination have no effect on the microleakage of open sandwich restorations.

\section{Material and methods}

\section{Specimen Preparation}

This study was approved by the Kurikkale University Institutional Review Board (Project no: 2018.10.08). Sixty extracted sound human molar teeth were collected, cleaned and polished with pumice and rubber cups for 10 seconds and kept in $0.1 \%$ thymol solution for up to 6 months after extraction until the test procedures were performed.

Class II slot cavities were prepared in mesial and distal surfaces with the gingival cavosurface margins which were located $1 \mathrm{~mm}$ below the cementoenamel junction. The overall dimensions of the cavities were standardized: the buccolingual width of the cavities was $1 / 3$ of intercuspal distance; the axiopulpal extension of the cavities was $3 \mathrm{~mm}$. The internal angles were rounded and cavosurface margins were sharp without bevel. The dimensions of the cavities were verified with a periodontal probe. All of the cavities were prepared by the use of a high-speed hand piece with cylindrical diamond bur (\# ISO110/012, Hicare Co, Guangzhou, China) under đer je postojala bojazan zbog adekvatne polimerizacije dijela staklenoionomernih materijala modificiranih smolom koji je smješten u dubokim kavitetima. Roberts i suradnici (8) preporučili su upotrebu konvencionalnih staklenih ionomera s visokim omjerom praha i tekućine za kavitete koji se protežu prema površini korijena. U dosadašnjim su istraživanjima Dietrich i suradnici (3) i Lougercio i suradnici (9) pokazali da upotreba staklenih ionomera modificiranih smolom za otvorenu sendvič-tehniku poboljšava rubnu prilagodbu restauracije. Nadalje, navode i da vezivanje kompozita na staklene ionomere modificirane smolom nije problem zbog sadržaja HEMA-e i da se ti materijali mogu lako vezati za smole na bazi metakrilata, poput kompozita (10).

U posljednjem desetljeću na dentalnom tržištu pojavio se hibridni staklenoionomerni materijal Equia-fil Forte (GC, SAD). Proizveden je disperzijom ultrafinih i visoko reaktivnih čestica stakla. Molekulska masa poliakrilne kiseline optimizirana je da bi se postigla optimalna čvrstoća i mehanička svojstva materijala. U mnogobrojnim su istraživanjima u in vitro i in vivo uvjetima procjenjivane performanse toga hibridnog staklenoionomernog sustava, a dobiveni rezultati bili su uspješni $(11-15)$.

No u literaturi ne postoji konsenzus o tehnikama minimiziranja mikropropuštanja na rubovima uz gingivu koji se nalaze u dentinu. Također nema dovoljno informacija o visokoviskoznim staklenim ionomerima koji se upotrebljavaju kao osnovni materijal u otvorenoj sendvič-tehnici i o kontaminaciji slinom. Zato su ciljevi ovog istraživanja sljedeći:

1. procijeniti rezultate mikropropuštanja uz rub gingive ispod caklinsko-cementnog spojišta u otvorenim sendvič-restauracijama II. razreda trima različitim staklenoionomernim materijalima i usporediti ih s kompozitnim materijalom

2. ispitati učinak kontaminacije slinom na rezultate mikropropuštanja u svim testiranim skupinama.

Nulta hipoteza istraživanja bila je da vrsta staklenoionomernog materijala i kontaminacija slinom ne utječu na mikropropusnost otvorenih sendvič-restauracija.

\section{Materijal i metode}

\section{Priprema uzoraka}

Ovo istraživanje odobrilo je Institucionalno povjerenstvo Sveučilišta Kurıkkale (br. projekta: 2018.10.08). Prikupljeno je šezdeset ekstrahiranih zdravih ljudskih kutnjaka koji su očišćeni i polirani gumicom 10 sekunda i pohranjeni u 0,1-postotnu otopinu timola do 6 mjeseci nakon vađenja, sve do početka istraživanja.

Na mezijalnim i distalnim plohama preparirani su kaviteti II. razreda $s$ aproksimalnim rubovima $1 \mathrm{~mm}$ ispod caklinskocementnog spojišta. Ukupne dimenzije kaviteta bile su standardizirane - bukolingvalna širina iznosila je $1 / 3$ in terkuspalne udaljenosti, a dubina $3 \mathrm{~mm}$. Unutarnji su kutovi zaobljeni, a kavopovršinski rubovi oštri i bez zakošenja. Dimenzije kaviteta provjerene su parodontološkom sondom. Svi kaviteti preparirani su turbinskim nastavkom $s$ cilindričnim dijamantnim svrdlom (ISO \#110/012, Hicare Co, Guangzhou, Kina), uz vodeno hlađenje. Uzorke je pripremio jedan istraživač. 
water cooling, which was changed in all 10 cavity preparations. Specimen preparations were performed by one operator who took a part in the study.

All of the materials were used according to the manufacturers' instructions in this study and shown in Table 1.

Teeth were randomly divided in 4 groups $(\mathrm{n}=15)$. In each specimen, mesial slot cavities were identified as no contamination groups and placement procedures of restorative materials in these cavities were described below. Thus, distal slot cavities in all restorative material groups were contaminated with saliva for 5 seconds with a micro brush, dried with cotton pellets and restored using the same protocol. Fresh human saliva was used in this study, collected immediately before application, from a healthy volunteer after the informed consent form had been signed.

Before the restorative material placement, a contoured matrix band with the Tofflemire matrix holder was placed around the teeth for restorative procedures and held by finger pressure against the gingival margin of the cavity.
Svi su materijali upotrijebljeni u skladu s uputama proizvođača, a navedeni su u tablici 1.

Zubi su nasumično podijeljeni $\mathrm{u}$ četiri skupine $(\mathrm{n}=15)$. U svakom su uzorku mezijalni kaviteti identificirani kao skupina bez kontaminacije, a postupak postavljanja restaurativnih materijala u te kavitete opisan je u nastavku. Tako su distalni kaviteti u svim skupinama kontaminirani slinom u trajanju od 5 sekunda mikročetkom, osušeni pamučnim peletima i restaurirani prema istom protokolu. U ovom istraživanju upotrijebljena je svježa ljudska slina od zdravog dobrovoljca nakon što je potpisao informirani pristanak.

Prije postavljanja restaurativnog materijala konturirana matrica s držačem Tofflemire postavljena je oko zuba i prstom pritisnuta uz gingivni rub kaviteta.

\begin{tabular}{|c|c|c|c|c|}
\hline $\begin{array}{l}\text { Material Description } \\
\text { Opis materijala }\end{array}$ & $\begin{array}{l}\text { Material • } \\
\text { Materijal }\end{array}$ & $\begin{array}{l}\text { Lot Number • } \\
\text { Serijski broj }\end{array}$ & $\begin{array}{l}\text { Manufacturer • } \\
\text { Proizvođač }\end{array}$ & Chemical Composition • Kemijski sastav \\
\hline $\begin{array}{l}\text { High-Viscous Glass Ionomer } \\
\text { Cement } \bullet \text { Visokoviskozni } \\
\text { staklenoionomerni cement }\end{array}$ & Fuji IX GP & 1610171 & $\begin{array}{l}\text { GC Corporation } \\
\text { Tokyo, Japan }\end{array}$ & $\begin{array}{l}\text { Powder: } \% 95 \text { aluminum-fluoro-silicate glass, } \% 5 \text { polyacrylic } \\
\text { acid powder. • Prašak: } 95 \% \text { - aluminij-fluoro-silikatno staklo, } 5 \\
\% \text { poliakrilna kiselina. } \\
\text { Liquid: } \% 50 \text { distilled water, } \% 40 \text { polyacrylic acid, and } \% 10 \\
\text { polybasic carboxylic acid } \bullet \text { Tekućina: } 50 \% \text { destilirana voda, } 40 \\
\% \text { poliakrilna kiselina i } 10 \% \text { polibazična karboksilna kiselina }\end{array}$ \\
\hline $\begin{array}{l}\text { Resin Modified Glass } \\
\text { Ionomer Cement } \bullet \\
\text { Staklenoionomerni cement } \\
\text { modificiran smolom }\end{array}$ & Fuji II LC & 1611011 & $\begin{array}{l}\text { GC Corporation } \\
\text { Tokyo, Japan }\end{array}$ & $\begin{array}{l}\% 25-50 \text { 2-hydroxyethyl methacrylate (HEMA), } \% 5-10 \\
\text { polybasic carboxylic acid, \%1-5 urethane dimethacrylate } \\
\text { (UDMA), \%1-5 dimethacrylate } \bullet 25-50 \% \text { 2-hidroksietil- } \\
\text { metakrilat (HEMA), 5-10\% polibazična karboksilna kiselina, } 1 \\
-5 \% \text { uretan dimetakrilat (UDMA), } 1-5 \% \text { dimetakrilat }\end{array}$ \\
\hline $\begin{array}{l}\text { Bulk-fill Glass Hybrid } \\
\text { Ionomer } \bullet \text { Hibridni } \\
\text { staklenoionomerni cement za } \\
\text { debeloslojnu tehniku }\end{array}$ & EQUIA-Fil Forte & 1707101 & $\begin{array}{l}\text { GC Corporation } \\
\text { Tokyo, Japan }\end{array}$ & $\begin{array}{l}\text { Powder: aluminum-fluoro-silicate glass, polyacrylic acid } \\
\text { powder, pigment. • Prašak: aluminij-fluoro-silikatno staklo, } \\
\text { poliakrilna kiselima, pigment } \\
\text { Liquid: Distilled water, polyacrylic acid, polybasic carboxylic } \\
\text { acid • Tekućina: destilirana voda, poliakrilna kiselina i } \\
\text { polibazična karboksilna kiselina }\end{array}$ \\
\hline $\begin{array}{l}\text { Microhybrid Resin } \\
\text { Composite } \bullet \text { Mikrohibridni } \\
\text { kompozit }\end{array}$ & G-aenial Posterior & 1805101 & $\begin{array}{l}\text { GC Corporation } \\
\text { Tokyo, Japan }\end{array}$ & $\begin{array}{l}\text { Pre-polymerized fillers }(16-17 \mu) \cdot \bullet \text { Prepolimerizirana punila } \\
(16-17 \mu) \text {. } \\
\text { Silica, strontium, lanthanide fluoride, fluoroaluminosilicate. } \bullet \\
\text { Silicij, stroncij, lantanidni fluorid, fluoroaluminosilikat }\end{array}$ \\
\hline $\begin{array}{l}\text { Universal Adhesive System • } \\
\text { Univerzalni adhezijski sustav }\end{array}$ & G-Premio Bond & 1712042 & $\begin{array}{l}\text { GC Corporation } \\
\text { Tokyo, Japan }\end{array}$ & $\begin{array}{l}\text { Functional monomers (4-MET, MDP and MDTP) 10-MDP, } \\
\text { acetone, dimethacrylate component, photoinitiator, butylated } \\
\text { hydroxytoluene. • Funkcijski monomeri (4-MET, MDP } \\
\text { i MDTP) 10-MDP, aceton, dimetakrilatne komponente, } \\
\text { fotoinicijator, butilirani hidroksitoluen }\end{array}$ \\
\hline
\end{tabular}

\section{Group I: High-Viscous Glass Ionomer (Fuji IX GP)}

The capsule form of high-viscous glass ionomer cement (Fuji IX GP, GC, Tokyo, Japan) was activated and was placed into an auto-mixer (RotoMix, 3M Espe, St Paul, MN, USA), mixed for 10 seconds. The dentin was conditioned with $20 \%$ polyacrylic acid for 10 seconds, rinsed and dried with a cotton pellet. A restorative material was placed to gingival floor in $1 \mathrm{~mm}$ thickness with a capsule applier, a plugger was used for condensation procedure, excess material was cleaned with

\section{Skupina I: Visokoviskozni stakleni ionomer (Fuji IX GP)}

Visokoviskozni staklenoionomerni cement u kapsuli (Fuji IX GP, GC, Tokio, Japan) aktiviran je i stavljen u automiješalicu (RotoMix, 3M Espe, St Paul, MN, SAD) da se miješa 10 sekunda. Dentin je 10 sekunda kondicioniran 20-postotnom poliakrilnom kiselinom, ispran i osušen pamučnom vaticom. Restaurativni materijal postavljen je na aproksimalni ormarić kaviteta u debljini od $1 \mathrm{~mm}$, nabijač je korišten za postupak kondenzacije, a višak materijala očišćen je mikro- 
a micro-brush and left undisturbed for 120 seconds until the initial setting time completed. A universal adhesive resin (GPremio Bond, GC, Tokyo Japan) was applied, air dried for 5 seconds and polymerized with a LED unit with a light intensity of $1200 \mathrm{~mW} / \mathrm{cm}^{2}$ (Elipar, 3M ESPE, USA) for $10 \mathrm{sec}-$ onds and a resin composite (G'aenial Posterior, GC, Tokyo Japan) was applied with incremental technique and each increment was light-cured for 20 seconds.

\section{Group II: Resin Modified Glass Ionomer (Fuji II LC)}

The capsule form of the resin modified glass ionomer cement (Fuji II LC, GC, Tokyo, Japan) was activated and was placed into an auto-mixer, mixed for 10 seconds. The dentin was conditioned with $20 \%$ polyacrylic acid for 10 seconds, rinsed and dried with a cotton pellet. A restorative material was placed to gingival floor in $1 \mathrm{~mm}$ thickness with a capsule applier, a plugger was used for condensation procedure and excess material was cleaned with a micro brush. Then, RMGIC layer was polymerized for $10 \mathrm{~s}$. A universal adhesive resin (G-Premio Bond) was applied, air dried for $5 \mathrm{~s}$ and polymerized for $10 \mathrm{~s}$ and a resin composite (G'aenial Posterior) was applied as described above.

\section{Group III: Glass Hybrid Ionomer (Equia-fil Forte)}

The capsule form of a glass hybrid ionomer material (Equia Forte, GC, Tokyo, Japan)was activated and was placed into an auto-mixer (RotoMix), mixed for 10 s. Cavity was rinsed and dried with a cotton pellet. A restorative material was placed to the gingival floor in $1 \mathrm{~mm}$ thickness with a capsule applier, a plugger was used for condensation procedure, the excess material was cleaned with a micro-brush and left undisturbed for 150 seconds until the initial setting time was completed. A universal adhesive resin (G-Premio Bond) was applied, air dried for 5 seconds and polymerized with a LED unit (Elipar S10, 3M ESPE, USA) and a resin composite (G'aenial Posterior) was applied as described above.

\section{Group IV: Resin Composite}

In this group, a universal adhesive resin (G- Premio Bond) was applied, air dried for 5 seconds and polymerized for 10 seconds. A resin composite material (G'aenial Posterior) was applied with incremental technique as described above.

After the restorative procedures, all teeth were stored in distilled water for 24 hours at $37^{\circ} \mathrm{C}$ in an incubator. The restorations were finished with ultra-fine grain diamond burs (\#ISO 166-016, \#ISO 257-018, Hicare Co, Guangzhou, China) and polishing was performed with fine grit silicone polishers (Nais Ltd, Sofia, Bulgaria) and aluminum oxide disks (Super Snap Rainbow Technique Kit, Shofu Dental, Kyoto, Japan) under water cooling.

\section{Thermocycling and Dye Penetration of the Specimens}

Specimens were kept in distilled water at $37^{\circ} \mathrm{C}$ for 24 hours and they were thermo-cycled for 10000 cycles at $5^{\circ} \mathrm{C}$ to $55^{\circ} \mathrm{C}$ (MTE 101 Thermocycling Machine, Esetron, Ankara, Turkey). The immersion time of each bath was 30 seconds and internal time was 10 seconds. The apical parts of the teeth were sealed using a resin composite (Filtek Z250, 3M, Espe, St. četkom i ostavljen 120 sekunda da se završi inicijalno stvrdnjavanje. Nanesen je univerzalni adheziv (G-Premio Bond, GC, Tokio Japan), ispuhan zrakom 5 sekunda i polimeriziran LED lampom snage svjetlosti $1200 \mathrm{~mW} / \mathrm{cm}^{2}$ (Elipar, 3M ESPE, SAD) tijekom 10 sekunda te je postavljen kompozitni materijal (G'aenial Posterior, GC, Tokio Japan) inkrementalnom tehnikom. Svaki sloj bio je osvijetljen 20 sekunda.

\section{Skupina II - stakleni ionomer modificiran smolom (Fuji II LC)}

Stakleni ionomer modificiran smolom u kapsuli (Fuji II LC, GC, Tokio, Japan) aktiviran je i stavljen u automješalicu da se miješa 10 sekunda. Dentin je 10 sekunda kondicioniran 20-postotnom poliakrilnom kiselinom, ispran i osušen pamučnom vaticom. Restaurativni materijal postavljen je na dno aproksimalnog kaviteta u debljini od $1 \mathrm{~mm}$, nabijač je korišten za postupak kondenzacije, a višak materijala očišćen je mikročetkom. Zatim je sloj cementa polimeriziran 10 sekunda. Upotrijebljen je univerzalni adheziv (G-Premio Bond), osušen je zrakom 5 sekunda i polimeriziran 10 sekunda te je nanesen kompozitni materijal (G'aenial Posterior) kao što je već opisano.

\section{Skupina III - hibridni stakleni ionomer (Equia-fil Forte)}

Hibridni stakleni ionomer u kapsuli (Equia Forte, GC, Tokio, Japan) aktiviran je i stavljen u automiješalicu (RotoMix) da se miješa 10 sekunda. Kavitet je ispran i osušen pamučnom vaticom. $\mathrm{Na}$ gingivno dno aproksimalnog kaviteta postavljen je restaurativni materijal u debljini od $1 \mathrm{~mm}$, nabijač je korišten za postupak kondenzacije, a višak materijala očišćen je mikročetkom i ostavljen 150 sekunda da se neometano završi inicijalno stvrdnjavanje. Nanesen je univerzalni adheziv (G-Premio Bond), osušen je zrakom 5 sekunda i polimeriziran LED svjetiljkom (Elipar S10, 3M ESPE, SAD) te je nanesen kompozitni materijal (G'aenial Posterior) kako je već opisano.

\section{Skupina IV - kompozitni materijal}

U ovoj skupini nanesen je univerzalni adheziv (G-Premio Bond), sušen je zrakom 5 sekunda i polimeriziran 10 sekunda. Nanesen je kompozitni materijal (G'aenial Posterior) inkrementalnom tehnikom kako je već opisano.

Nakon restaurativnih postupaka svi su zubi čuvani u destiliranoj vodi 24 sata na $37^{\circ} \mathrm{C}$ u inkubatoru. Restauracije su završno obrađene ultrafinim dijamantnim svrdlima (ISO \#166-016, ISO \#257-018, Hicare Co, Guangzhou, Kina) te polirane silikonskim polilerima (Nais Ltd, Sofija, Bugarska) $\mathrm{i}$ aluminij-oksidnim diskovima (Super Snap Rainbow Technique Kit, Shofu Dental, Kyoto, Japan) uz vodeno hlađenje.

\section{Termocikliranje i prodiranje boje u uzorke}

Uzorci su bili 24 sata pohranjeni u destiliranoj vodi na temperaturi od $37^{\circ} \mathrm{C}$ u inkubatoru i termociklirani u 10000 ciklusa na $5^{\circ} \mathrm{C}$ do $55^{\circ} \mathrm{C}$ (MTE 101 termociklički stroj, Esetron, Ankara, Turska). Vrijeme uranjanja u svaku kupku bilo je 30 sekunda, a unutarnje vrijeme 10 sekunda. Apikalni dijelovi zuba zapečaćeni su kompozitom (Filtek Z250, 3M, Espe, 
Paul, MN, USA) then they were coated with nail varnish up to $1 \mathrm{~mm}$ to the restoration margins. Then, specimens were immersed in a \% 0,5 methylene blue dye solution for 24 hours. After immersion procedure, all teeth were rinsed under running water. They were embedded in autopolymerizing acrylic resin through the $1 / 3$ of the root apices. They were sectioned vertically through the center of the restorations from mesial to distal surface with a water-cooled diamond saw with $1 \mathrm{~mm}$ thickness (Microcut 151, Metkon, Istanbul, Turkey).

Dye penetration was evaluated at gingival, occlusal margins and interface between glass ionomer and resin composite at 20X magnification using a stereomicroscope (Nexius Zoom, Euromex Microscopen BV, Arnheim, Netherlands). Photographs were saved as TIFF images and processed with a MacBook device. The extent of dye penetration was evaluated quantitatively using the image analysis software (Image J,V.1.42, National Institutes of Health, Bethesda,MD).

\section{Statistical Analysis}

The results were statistically analyzed using the statistical software IBM SPSS for Windows version 22.0 software package (IBM SPSS, New York, ABD). The data were analyzed using One-way ANOVA with the significance level set at 0.05 . The Tukey HSD and Student t-tests were performed for multiple comparisons.

\section{Results}

The mean microleakage scores in milimeters $(\mathrm{mm})$ of all groups were shown in Table 2 and Figure 1.
St. Paul, MN, SAD) i zatim premazani lakom za nokte do 1 $\mathrm{mm}$ od ruba restauracije. Zatim su uzorci 24 sata uronjeni u 0,5-postotnu otopinu metilenskog modrila. Nakon postupka uranjanja svi su zubi isprani tekućom vodom. Ugrađeni su $\mathrm{u}$ autakrilat. Prerezani su, uz vodeno hlađenje, dijamantnom pilom debljine $1 \mathrm{~mm}$ (Microcut 151, Metkon, Istanbul, Turska) vertikalno kroz središte restauracije od mezijalne do distalne plohe.

Prodiranje boje procijenjeno je na gingivocervikalnom i okluzalnom rubu na sučelju između staklenog ionomera i kompozita pri povećanju od 20 puta s pomoću stereomikroskopa (Nexius Zoom, Euromex Microscopen BV, Arnheim, Nizozemska). Fotografije su spremljene kao TIFF datoteke i obrađene MacBook uređajem. Stupanj prodiranja bojila kvantitativno je procijenjen softverom za analizu slika (slika J, V.1.42, National Institutes of Health, Bethesda, MD, $\mathrm{SAD})$.

\section{Statistička analiza}

Rezultati su statistički analizirani statističkim softverom IBM SPSS za Windowse, inačicom 22.0 softverskog paketa (IBM SPSS, New York, SAD). Podatci su analizirani jednosmjernom ANOVA-om s razinom značajnosti postavljenom na 0,05 . Tukeyijev HSD i Studentov t-test provedeni su u višestrukim usporedbama.

\section{Rezultati}

Prosječni rezultati mikropropuštanja u svim skupinama nalaze se u tablici 2. i na slici 1 . Uočena je statistički značajna

Table 2 Mean microleakage scores of groups tested(Mean \pm SD).

Tablica 2. Srednje vrijednosti ispitivanja mikropropusnosti po skupinama (srednja vrijednost \pm SD)

\begin{tabular}{l|c|c|c|c} 
& \multicolumn{2}{|c}{ No contamination $\bullet$ Bez kontaminacije } & \multicolumn{2}{c}{ Saliva contaminated $\bullet$ Kontaminacija slinom } \\
\cline { 2 - 5 } Group I • Skupina I & Occlusal $\bullet$ Okluzalno & Gingival $\bullet$ Uz gingivu & Occlusal $\bullet$ Okluzalno & Gingival $\bullet$ Uz gingivu \\
\hline Group II $・$ Skupina II & $0.1 \pm 0.02^{\mathrm{a}}$ & $1.07 \pm 0.85^{\mathrm{b}}$ & $0.1 \pm 0.02^{\mathrm{a}}$ & $0.66 \pm 0.58^{\mathrm{a}}$ \\
\hline Group III • Skupina III & $0.24 \pm 0.44^{\mathrm{a}}$ & $0.49 \pm 0.59^{\mathrm{a}}$ & $0.39 \pm 0.48^{\mathrm{a}}$ & $0.65 \pm 0.83^{\mathrm{a}}$ \\
\hline Group IV • Skupina IV & $0.1 \pm 0.02^{\mathrm{a}}$ & $0.44 \pm 0.49^{\mathrm{a}}$ & $0.18 \pm 0.29^{\mathrm{a}}$ & $0.36 \pm 0.59^{\mathrm{a}}$ \\
\hline
\end{tabular}

${ }^{*}$ Groups with distinct superscripts exhibit statistically significant differences in column $(\mathrm{p}<0.05)$. $\bullet$ Skupine $s$ različitim slovima u superskriptu pokazale su statistički značajne razlike unutar stupca $(\mathrm{p}<0,05)$

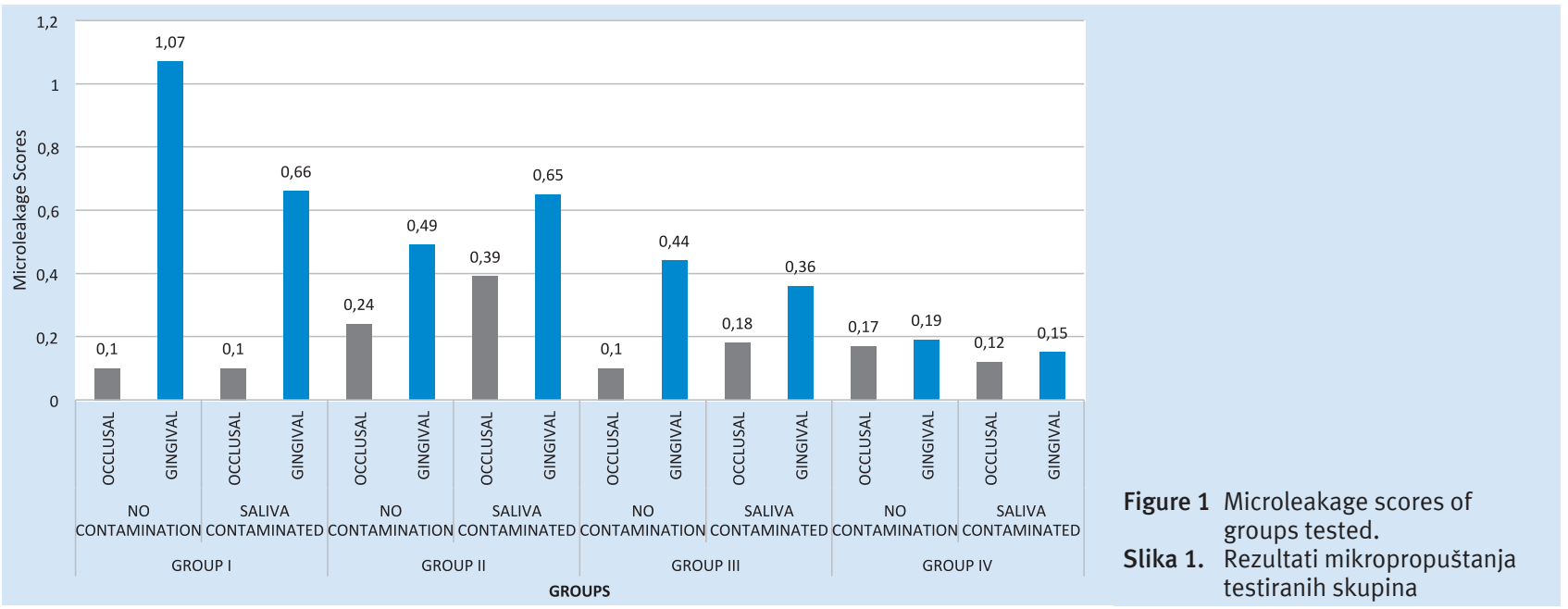


There was a statistically significant difference between no contamination groups $(\mathrm{p}<0.05)$. The high-viscous glass ionomer group, Fuji IX GP demonstrated higher gingival microleakage scores than other groups tested. However, in saliva contaminated groups, gingival microleakage scores indicated similar results and no statistically significant difference was shown ( $p>0.05)$. The results of the present study also demonstrated that saliva contamination did not significantly affect the microleakage scores in no contamination and saliva contaminated groups regardless of margin localization and dental materials tested $(p>0.05)$. No dye penetration was observed in the interface of glass ionomer materials and resin composite in open sandwich restoration groups.

\section{Discussion}

The present study evaluated the microleakage of class II slot open sandwich restorations performed with a high-viscous glass-ionomer, resin modified glass-ionomer and glass hybrid ionomer materials in case of saliva contamination. According to our results, in no contamination groups, glass ionomer material type affected the gingival microleakage scores. However, saliva contamination did not demonstrate adverse effects in microleakage scores. Therefore, the null hypothesis was partially rejected.

Although different techniques have been used to evaluate microleakage $(16,17)$, the dye penetration method was selected for the present study. Although, the semi quantitative dye penetration technique was widely accepted method for in vitro studies, clinical relevance was questioned in a recent systematic review (18). However, this technique is easy and fast. Also, it is still a preferred screening method to compare restorative materials (19-21).

The gingival margin of Class II restorations, extended to the root surface demonstrated microleakage according to isolation problems, polymerization shrinkage of composite material (22) and distance to the tip of the polymerization unit (3). These factors could lead to an inadequate marginal adaptation, thus affecting the longevity of a resin restoration (23). The difficulties with class II restorations have led to the development of open sandwich technique, as glass ionomer or resin modified glass ionomer material, which is placed to gingival margin and completed with a resin composite in occlusal part of the cavity. Koubi et al. (24) observed that in open sandwich restorations, resin modified glass ionomer material, Fuji II LC was the best intermediate material. However, Moazzami et al. (16) evaluated the effect of different materials (resin modified glass ionomer, compomer and self-curing resin, flowable composite resin) on the gingival microleakage of Class II open sandwich restorations. As a result, none of the materials enhanced the microleakage scores. In the present study, in no contamination group, high-viscous glass ionomer group showed the greatest leakage scores, which is in accordance with the results of a previous study conducted by Lougercio et al. (9). The authors compared the gingival microleakage of Class II resin restorations and open sandwich restorations and found poor results in a traditional glass ionomer group. Some studies $(6,7,25)$ found out that the con- razlika između skupina bez kontaminacije $(\mathrm{p}<0,05)$. U skupini visokoviskoznog staklenog ionomerna Fuji IX GP zabilježen je veći stupanj mikropropuštanja negoli u ostalima. No u skupinama kontaminiranima slinom rezultati mikropropuštanja bili su slični i nije bilo statistički značajne razlike (p > $0,05)$. Rezultati ovog istraživanja također su pokazali da kontaminacija slinom nije značajno utjecala na rezultate mikropropuštanja u nekontaminiranim i kontaminiranim skupinama, bez obzira na lokalizaciju ruba i testirani stomatološki materijal $(p>0,05)$. Na sučelju staklenoionomernih materijala i kompozita nije uočeno prodiranje boje u skupinama s otvorenom sendvič-tehnikom.

\section{Rasprava}

U ovom istraživanju analizirala se mikropropusnost restauracija II. razreda izrađenih otvorenom sendvič-tehnikom uz primjenu visokoviskoznog staklenog ionomera, staklenog ionomera modificiranog smolom i hibridnog staklenog ionomerima u slučaju kontaminacije slinom. Prema našim rezultatima, ni u jednoj kontaminiranoj skupini vrsta staklenoionomernog materijala nije utjecala na rezultate mikropusnosti uz rub gingive. Kontaminacija slinom nije štetno utjecala na rezultate mikropropuštanja. Zato je nulta hipoteza djelomično odbačena.

Postoje različite tehnike ocjenjivanja mikropropusnosti $(16,17)$, a u ovom je istraživanju odabrana metoda prodiranja boje. Iako je tehnika kvantitativnog prodiranja boje široko prihvaćena metoda u istraživanjima in vitro, klinička relevantnost dovedena je u pitanje u nedavno objavljenom sistematiziranom preglednom radu (18). No ta je tehnika jednostavna i brza. Također se još uvijek preferira metoda probira za usporedbu restaurativnih materijala $(19-21)$.

Gingivni rub kod kaviteta II. razreda koji se proteže na površinu korijena otežava izolaciju i u kombinaciji s polimerizacijskim skupljanjem kompozitnog materijala (22) i zbog velike udaljenosti vrha polimerizacijske svjetiljke (3) pogoduje rubnom mikropropuštanju. Ti čimbenici mogu potaknuti neadekvatnu rubnu prilagodbu, što utječe na trajnost restauracije (23). Poteškoće s restauracijama II. razreda rezultirale su razvojem otvorene sendvič-tehnike kod koje se stakleni ionomer ili stakleni ionomer modificiran smolom postavlja na dno kaviteta uz rub gingive i upotpunjava kompozitom u okluzalnom dijelu. Koubi i suradnici (24) istaknuli su da je smolom modificirani stakleni ionomer Fuji II LC najbolji posrednički materijal u otvorenim sendvič-restauracijama. No Moazzami i suradnici (16) analizirali su utjecaj različitih materijala (staklenih ionomera modificiranih smolom, kompomera, autopolimerizirajućih smola, tekućih kompozita) na mikropropusnost otvorenih sendvič-restauracija II. razreda. Nijedan materijal nije poboljšao rezultat mikropropusnosti. $U$ ovom istraživanju, u nekontaminiranoj skupini, za visokoviskozni staklenoionomerni cement zabilježen je najveći stupanj propuštanja, što je u skladu $s$ rezultatima istraživanja koje su proveli Lougercio i suradnici (9). Autori su uspoređivali mikropropusnost restauracija II. razreda i otvorenih sendvič-restauracija i dobili loše rezultate u skupini tradicionalnih staklenoionomernih 
traction forces which occurred during polymerization of resin composite were sufficiently strong to disrupt the bond between a glass ionomer and the dentin, mainly in the initial stages of the glass-ionomer cement maturation. Hence, they might be blamed for the poor results observed in this group. However, in the present study, there were no statistically significant differences in gingival leakage scores in saliva-contaminated groups. This may be explained by the behavior of conventional glass ionomer at the time of placement. The dentin at the dentin-restorative interface should not be overdried and saliva could moisturize the surface, which resulted in a good adhesion in our study. It could be also related to the chemical composition and the technique sensitivity of materials tested. Similar to our results, Dietrich et al., in a previous study (25), reported that sandwich restorations seem to be less sensitive to contamination with saliva and blood. The results of some studies demonstrated no effect of saliva contamination on bond strength and marginal adaptation (26, 27). Dursun and Attal (28) also demonstrated that saliva contamination, regardless of time, did not significantly affect the dentin bond strength when a self-etch adhesive system was used with a resin modified glass ionomer. Saliva contamination time could have an important effect on these results since we contaminated the cavities before acidic primer application for high-viscous and resin modified glass ionomer groups and adhesive application for resin composite groups. Ludlow et al. showed higher microleakage scores when the contamination occurred after the acidic primer application (29).

In the present study, among experimental glass ionomers, the best marginal sealing was obtained when a hybrid glass ionomer (Equia-fil Forte) was used and the open sandwich technique was employed. However, a conventional glass ionomer Fuji IX GP showed the worst microleakage results in no saliva contamination groups. Additionally, the best marginal leakage scores were obtained in the resin composite group. In a previous study, Miller et al. (30) evaluated the marginal microleakage of different materials in sandwich restorations and obtained good results when resin modified glass ionomer and compomers were used as a base material under the resin composites. They obtained good results even in the resin composite group, without any base material in the gingival margin.

One of the limitations of the open sandwich technique was adaptation of two different material increments and bonding the interface of the materials in a restoration. Shafiei and Akbarian (31) demonstrated no dye penetration at the interface of a nano ionomer and composites specimens, or only a slight dye penetration. Similar to their results, in our study, perfect adhesion was obtained between all glass ionomer materials and the resin composite layer. This result could be associated with the use of universal adhesive, posterior composite and incremental technique, achieving a good bond between materials in the present study. Universal adhesives contain functional monomers such as 10-MDP and can be used in self-etch or etch-and-rinse mode. Simple clinical procedures and ability to bond to various substrates gained popularity to these adhesive systems. Francois et al.(13) demonstrated similar shear bond strength values of resin compos- cemenata. U nekim istraživanjima autori su istaknuli $(6,7$, 25) da su sile kontrakcije koje su se dogodile tijekom polimerizacije kompozita bile dovoljno jake da prekinu vezu između staklenog ionomera i dentina, uglavnom u početnim fazama stvrdnjavanja staklenoionomernog cementa. To bi mogao biti uzrok loših rezultata u toj skupini. No u ovom istraživanju nije bilo statistički značajnih razlika u rezultatima mikropropusnosti uz rub gingive u skupinama kontaminiranima slinom. To se može objasniti ponašanjem konvencionalnog staklenog ionomera u vrijeme postavljanja. Dentin na sučelju s restauracijom ne smije se presušiti, a slina bi mogla navlažiti površi$\mathrm{nu}$, što je rezultiralo dobrom adhezijom u našem istraživanju. Može se povezati i s kemijskim sastavom i osjetljivošću testiranih materijala na proceduralne pogreške. Slično našim rezultatima, Dietrich i suradnici u svojem su istraživanju (25) izvijestili da su restauracije izrađene sendvič-tehnikom manje osjetljive na kontaminaciju slinom i krvlju. Rezultati nekih istraživanja nisu pokazali utjecaj kontaminacije slinom na veznu čvrstoću i rubnu prilagodbu $(26,27)$. Dursun i Attal (28) također su istaknuli da kontaminacija slinom, bez obzira na vrijeme, nije značajno utjecala na veze čvrstoće $s$ dentinom kada se primjenjivao samojetkajući adhezijski sustav sa staklenoionomerom modificiranim smolom. Trenutak kontaminacije slinom mogao bi imati važan utjecaj na ove rezultate jer smo kontaminirali kavitete prije nanošenja kiselog primera u skupinama s visokoviskoznim i smolom modificiranim staklenom ionomerom ili adehziva u skupini s kompozitnim materijalom. Ludlow i suradnci zabilježili su veći stupanj mikropropuštanja kada se kontaminacija dogodila nakon nanošenja kiselog primera (29).

U ovom istraživanju, među testiranim staklenim ionomerima, najbolje rubno brtvljenje postignuto je kada je korišsten hibridni stakleni ionomer (Equia-fil Forte) i tehnika otvorenog sendviča. Konvencionalni stakleni ionomer Fuji IX GP pokazao je najlošije rezultate u mikropropusnosti u skupinama bez kontaminacije slinom. Najbolji rezultati rubnog propuštanja dobiveni su u skupini s kompozitnim materijalom. U svojem su istraživanju Miller i suradnici (30) ocjenjivali rubnu mikropropusnost različitih materijala u restauracijama izrađenima sendvič-tehnikom i dobili su dobre rezultate kada su stakleni ionomeri modificirani smolom i kompomeri upotrijebljeni kao podloga ispod kompozita. Rezultati su čak bili dobri i u skupini kompozita bez ikakve podloge uz rub gingive.

Jedno od ograničenja tehnike otvorenog sendviča bilo je prilagođavanje dvaju različitih slojeva materijala i vezanje materijala na sučelju restauracije. Shafiei i Akbarian (31) nisu utvrdili prodiranje boje na sučelju nanoionomera i kompozita, ili se dogodilo blago prodiranje boje. Slično njihovim rezultatima, u našem istraživanju postignuta je savršena adhezija između svih staklenoionomernih materijala i kompozita. Taj se rezultat može povezati s korištenjem univerzalnog adheziva, kompozita za stražnje zube i inkrementalne tehnike, čime je postignuta dobra veze između materijala. Univerzalni adhezivi sadržavaju funkcijske monomere kao što je 10-MDP i mogu se upotrebljavati u samojetkajućoj ili jetkajuće-ispirućoj tehnici. Jednostavni klinički postupci i svojstvo vezanja na različite podloge pridonijeli su popularnosti tih 
ite bonded to Equia-fil Forte using a universal adhesive in self-etch mode and in etch-and-rinse mode. In our study, GPremio Bond universal was preferred in self-etch mode and it demonstrated good results in control and saliva-contaminated groups in terms of microleakage. In difficult clinical conditions, this technique could be less time-consuming and less sensitive to achieve better marginal adaptation in class II extensive restorations.

Czarnecka et al.(32) evaluated the adhesion of Fuji IX GP, Fuji II LC and two other glass ionomer materials in slot cavities and noticed problems in establishing a contact between the material and internal walls of the cavity due to handling and the placement of a thin layer of cement. Although the capsule form of all glass ionomers was used in our study, it was not easy to control fluidity of glass ionomer material in the cavity as a base. In some microleakage studies $(12,33,34)$, glass ionomer materials were applied to the entire cavity using the bulk technique and from clinical point of view, this could be easier than to place a thin layer at the gingival margin. Besides, the application tips of the capsules were not designed to reach narrow spaces such as gingival margins of slot restorations.

Recently, a new material with all advantages of glass ionomers such as fluoride release, hydrophilic nature and enhanced mechanical properties has been introduced to the dental market (35-37). Francois et al.(13) speculated that this resin-free and biocompatible characteristics might be useful for the sandwich technique or proximal margin sealing. Moshaverinia et al. reported that Equia-fil Forte is a powerful restorative material with a wide range of clinical applications in dental practice (38). In another study, it was reported that Equia Forte was significantly more rigid and less deformed than other materials under functional stress, thus supporting its indication for posterior restorations (39). This in vitro result was supported by a clinical follow up study of class II restorations performed by Gürgan et al.(14) The development of such materials might be promising for the clinicians in terms of restorations extended margins to the root surface. In the present study, Equia-fil Forte demonstrated acceptable microleakage results at gingival margins compared to Fuji II LC and G'aenial Posterior without any conditioner application.

One of the limitations of the present study was only thermocycling which was performed as aging procedure for the restorations. However, mechanical loading could affect the marginal adaptation of restorations in gingival area and the results could mimic clinical conditions in a better way than in the current study. Further studies are needed to clarify this issue in the future. Laboratory tests have also numerous drawbacks. The clinical behavior of restorative materials needs to be simulated. The obtained results need to be supported by long-term clinical trials.

\section{Conclusion}

Saliva contamination mostly occurs in posterior restorations with gingival cavosurface margins located in the root dentin. Within the limitations of this study, no adverse effect adhezijskih sustava. Francois i suradnici (13) dobili su slične vrijednosti posmične vezne čvrstoće kompozitnih materijala vezanih na Equia-fil Forte koristeći se univerzalnim adhezivom u samojetkajućoj i jetkajuće-ispirućoj tehnici. U našem istraživanju je G-Premio Bond Universal korišsten u samojetkajućoj tehnici i pokazao je dobre rezultate u mikropropusnosti u kontrolnoj skupini i skupinama kontaminiranima slinom. U teškim kliničkim uvjetima ta bi tehnika mogla zahtijevati manje vremena i biti manje osjetljiva na proceduralne pogreške, čime bi se postigla bolja rubna prilagodba u velikim restauracijama II. razreda.

Czarnecka i surdnci (32) analizirali su adheziju cemenata Fuji IX GP, Fuji II LC i dvaju drugih staklenoionomernih materijala u kavitetima te su uočili probleme u postizanju kontakta između materijala i unutarnjih stijenki kaviteta zbog rukovanja i aplikacije tankoga sloja cementa. Iako su u našem istraživanju svi stakleni ionomeri korišteni u obliku kapsula, nije bilo jednostanno kontrolirati fluidnost materijala u kavitetu. U nekim istraživanjima o mikropropusnosti $(12,33,34)$, staklenoionomerni materijali naneseni su u cijeli kvitet, a s kliničkog stajališta to bi moglo biti jednostavnije negoli postaviti tanki sloja uz rub gingive. Osim toga, vrh kapsule nije oblikovan tako da može dosegnuti uske prostore.

Nedavno je na tržištu predstavljen novi materijal sa svim prednostima staklenih ionomera poput oslobađanja fluora, hidrofilne prirode i poboljšanih mehaničkih svojstava (3537). Francois i suradnici (13) pretpostavljali su da bi karakteristike tih materijala, poput biokompatibilnosti i činjenice da ne sadržavaju smole, mogle biti korisne za sendvič-tehniku ili brtvljenje aproksimalnih rubova. Moshaverinia i suradnici izvijestili su da je Equia-fil Forte moćan restaurativni materijal sa širokom kliničkom primjenom u stomatološkoj praksi (38). U jednom drugom istraživanju objavljeno je da je Equia Forte bio mnogo rigidniji i manje se deformirao od ostalih materijala koji su bili pod funkcijskim naprezanjem, što ide u prilog njegovoj indikaciji za restauracije na stražnjim zubima (39). Ovaj rezultat in vitro potkrijepljen je kliničkim praćenjem restauracija II. razreda koje su proveli Gürgan i suradnici (14). Razvoj takvih materijala mogao bi biti obećavajući za restauracije čiji se rubovi protežu na površinu korijena. $\mathrm{U}$ ovom istraživanju je Equia-fil Forte postigao bolje rezultate mikropropusnosti na rubovima uz gingivu u usporedbi $s$ Fujiem II LC i G'aenial Posteriorom i bez kondicioniranja.

Jedno od ograničenja ovog istraživanja jest što je kao postupak starenja restauracija provedeno samo termocikliranje. Mehaničko opterećenje moglo bi utjecati na rubnu prilagodbu restauracija u gingivnom području i rezultati bi mogli oponašati kliničke uvjete na bolje negoli u ovom istraživanju. Potrebna su dodatna istraživanja kako bi se to pitanje razjasnilo. Laboratorijski testovi također imaju mnoge nedostatke. Treba simulirati ponašanje restaurativnih materijala u kliničkim uvjetima. Dobivene rezultate potrebno je potvrditi dugoročnim kliničkim istraživanjima.

\section{Zaključak}

Kontaminacija slinom uglavnom se događa na stražnjim restauracijama s cervikalnim rubovima smještenima u korijenskom dentinu. Uzimajući u obzir ograničenja ovog istra- 
of saliva contamination has been demonstrated on microleakage of restorations performed with open sandwich technique in gingival and occlusal margins regardless of dental materials tested. Glass hybrid ionomers and resin modified glass ionomers showed lower microleakage scores in gingival margins compared to a high-viscous glass ionomer material in no contamination groups, hence they might have been preferred in cases where isolation was not a problem.

\section{Acknowledgment}

The authors would like to gratefully acknowledge the support of Associate professor Serkan Erat, Kırıkkale University, Faculty of Veterinary Science for statistical analysis.

\section{Conflict of interest}

The authors declare that they have no conflict of interest.

\section{Contribution to the paper}

C.C. Author, research methodology, analysis of the results; Y.B. microleakage tests, stereomicroscope evaluation; B.E.Ö. Specimen preparation živanja, nije dokazan štetan učinak kontaminacije slinom na mikropropunost restauracija koje su izrađene otvorenom sendvič-tehnikom na cervikalnim i okluzalnim rubovima, bez obzira na testirane dentalne materijale. Hibridni stakleni ionomeri i stakleni ionomeri modificirani smolom imali su manji stupanj mikropropuštanja uz gingivni rub u odnosu prema visokoviskoznom staklenom ionomeru u nekontaminiranim skupinama i zato bi im se trebala dati prednost u slučaju kada izolacija nije problem.

\section{Zahvala}

Autori zahvaljuju profesoru Serkanu Eratu s Veterinarskog fakulteta Sveučilišta Kırıkkale za iznimnu potporu.

\section{Sukob interesa}

Autori nisu bili u sukobu interesa.

\section{Doprinos radu}

C. C. - autor, metodologija istraživanja, analiza rezultata; Y. B. - testovi mikropropuštanja, analiza stereomikroskopom; B. E. Ö. - priprema uzoraka

\begin{abstract}
Sažetak
Svrha istraživanja: Željela se procijeniti mikropropusnost konvencionalnih staklenih ionomera, smolom modificiranih staklenih ionomera i hibridnih staklenih ionomera u otvorenim restauracijama II. razreda kontaminiranih slinom ili nekontamitiranih slinom. Materijal i metode: Korišteno je 60 ekstrahiranih zdravih ljudskih kutnjaka i preparirano je 120 kaviteta II. razreda na mezijalnim i distalnim plohama. Rubovi gingive nalazili su se $1 \mathrm{~mm}$ ispod caklinsko-cementnog spojišta. Svi uzorci nasumično su podijeljeni u četiri skupine $(n=15)$ : skupina I - visoko viskozni stakleni ionomer (Fuji IX GP); skupina II - smolom modificirani stakleni ionomer (Fuji II LC); skupina III - hibridni stakleni ionomer (Equia-fil Forte); skupina IV - kompozitna smola (G'aenial Posterior). U skupini s otvorenim sendvič-restauracijama staklenoionomerni materijali postavljeni su na gingivno dno u debljini od $1 \mathrm{~mm}$, a ostatak kaviteta ispunjen je kompozitnim materijalom. Nakon izrade restauracije na mezijalnim plohama, distalni kaviteti restaurirani su prema istom protokolu nakon kontaminacije slinom. Uzorci su podvrgnuti termocikliranju od 10000 ciklusa na temperaturi od $5^{\circ} \mathrm{C}$ do $55^{\circ} \mathrm{C}$ i uronjeni tijekom 24 sata u otopinu metilenskog modrila $(\%, 0,5)$. Zatim su se prerezani dijamantnom pilom, uz vodeno hlađenje, vertikalno kroz središte restauracije od mezijalne plohe prema distalnoj na debljinu od $1 \mathrm{~mm}$. Nakon toga je prodiranje boje procjenjivano softverom za analizu slika. Podatci su statistički analizirani $(p<0,05)$. Rezultati: Uočena je statistički značajna razlika između rezultata mikropropuštanja u skupinama bez kontaminacije, između visokoviskoznog staklenog ionomera Fuji IX GP i ostalih testiranih materijala $(p<0,05)$. U skupinama kontaminiranima slinom nije bilo statistički značajne razlike između rezultata mikropropuštanja $(p>0,05)$. Uz to, nije bilo statistički značajne razlike između skupina kontaminiranih slinom i nekontaminiranih slinom, neovisno o testiranim dentalnim materijalima $(p>0,05)$. Zaključak: Uzimajući u obzir ograničenja ovog istraživanja, u otvorenim sendvič-restauracijama kontaminacija slinom nije štetno utjecala na mikropropuštanje, bez obzira na testirane dentalne materijale. Hibridni stakleni ionomeri i stakleni ionomeri modificirani smolom pokazali su lošije rezultate u mikropropusnosti na gingivnim rubovima u odnosu prema visokoviskoznim staklenoionomernim materijaloma u skupini bez kontaminacije.
\end{abstract}

Zaprimljen: 30. siječnja 2020

Prihvaćen: 29. srpnja 2020.

Adresa za dopisivanje Profesor Çiğdem Çelik Kırıkkale sveučilište

Stomatološki fakultet Zavod za restaurativnu stomatologiju Yenişehir Mh. Çelebi Sok. No: 171450 Yahşihan

Kırıkkale, Turkey

Telefon: +90 3182244927

ccelik75@gmail.com

\section{Ključne riječi}

otvorene sendvič-restauracije, stakleni ionomeri, kompozitne smole, trajni zuni ispun; dentalno propuštanje;

\section{References}

1. Ehrnford L, Derand T. Cervical gap formation in class II composite resin restorations. Swed Dent J. 1984;8(1):15-9.

2. Aboushala A, Kugel G, Hurley E. Class II composite resin restorations using glass-ionomer liners: microleakage studies. J Clin Pediatr Dent. Fall 1996;21(1):67-70.

3. Dietrich T, Lösche A, Lösche G, Roulet J-F. Marginal adaptation of direct composite and sandwich restorations in Class II cavities with cervical margins in dentin. J Dent. 1999 Feb;27(2):119-28.

4. McCabe JF. Resin-modified glass-ionomers. Biomaterials. 1998 Mar;19(6):521-7.

5. Crim GA, Chapman KW. Reducing microleakage in Class II restorations: An in vitro study. Quintessence Int. 1994 Nov;25(11):7815 .
6. Reid J, Saunders W, Sharkey S, Williams C. An in-vitro investiga tion of microleakage and gap size of glass ionomer/composite resin" sandwich" restorations in primary teeth. ASDC J Dent Child Jul-Aug 1994;61(4):255-9.

7. Subrata G, Davidson C. The effect of various surface treatments on the shear strength between composite resin and glass-ionomer cement. J Dent. 1989 Feb;17(1):28-32.

8. Roberts HW, Berzins DW, Charlton DG. Hardness of three resin-modified glass-ionomer restorative materials as a function of depth and time. J Esthet Restor Dent. 2009;21(4):262-72.

9. Loguercio AD, Reis A, Mazzocco KC, Dias AL, Busato ALS, da Motta Singer J, et al. Microleakage in class II composite resin restorations: total bonding and open sandwich technique. J Adhes Dent. 2002;4(2):137-144. 
10. Burrow MF. Physicochemical Nature of Glass-lonomer-Based Materials and Their Clinical Performance. Glass-Ionomers in Dentistry: Springer; 2016. p. 25-56.

11. Kutuk Z, Ozturk C, Cakir F, Gurgan S. Mechanical performance of a newly developed glass hybrid restorative in the restoration of large MO Class 2 cavities. Niger J Clin Pract.2019;22(6):833.

12. Bahsi E, Sagmak S, Dayi B, Cellik O, Akkus Z. The evaluation of microleakage and fluoride release of different types of glass ionomer cements. Niger J Clin Pract. 2019 Jul;22(7):961-970.

13. Francois $P$, Vennat E, Le Goff $S$, Ruscassier N, Attal J-P, Dursun E. Shear bond strength and interface analysis between a resin composite and a recent high-viscous glass ionomer cement bonded with various adhesive systems. Clin Oral Investig. 2019 Jun;23(6):2599-2608.

14. Gurgan S, Kutuk Z, Ozturk C, Soleimani R, Cakir F. Clinical Performance of a Glass Hybrid Restorative in Extended Size Class II Cavities. Oper Dent. May/Jun 2020;45(3):243-254.

15. Šalinović I, Stunja M, Schauperl Z, Verzak Ž, Ivanišević Malčić A, Brzović Rajić V. Mechanical Properties of High Viscosity Glass lonomer and Glass Hybrid Restorative Materials. Acta Stomatol Croat. 2019 Jun;53(2):125-131.

16. Moazzami S, Sarabi N, Hajizadeh H, Majidinia S, Li Y, Meharry M, et al. Efficacy of four lining materials in sandwich technique to reduce microleakage in class II composite resin restorations. Oper Dent. May-Jun 2014;39(3):256-63.

17. Heintze SD. Clinical relevance of tests on bond strength, microleakage and marginal adaptation. Dent Mater. 2013 Jan;29(1):5984.

18. Hickel R, Roulet J-F, Bayne S, Heintze SD, Mjoer IA, Peters M, et al. Recommendations for conducting controlled clinical studies of dental restorative materials. Science Committee Project 2/98 -FDI World Dental Federation study design (Part I) and criteria for evaluation (Part II) of direct and indirect restorations including onlays and partial crowns. J Adhes Dent. 2007;9 Suppl 1:121-47.

19. Ayna B, Celenk S, Atas O, Tümen E, Uysal E, Toptanci I. Microleakage of glass ionomer based restorative materials in primary teeth: An In vitro study. Niger J Clin Pract.2018;21(8):1034-7.

20. Hepdeniz O, Ermis R. Comparative evaluation of marginal adaptation and microleakage of low-shrinking composites after thermocycling and mechanical loading. Niger J Clin Pract.2019;22(5):633.

21. García L, Gil Ac, Puy Cl. In vitro evaluation of microleakage in Class II composite restorations: High-viscosity bulk-fill vs conventional composites. Dent Mater J. 2019 Oct 2;38(5):721-727.

22. Davidson C, Feilzer A. Polymerization shrinkage and polymerization shrinkage stress in polymer-based restoratives. J Dent. 1997 Nov;25(6):435-40.

23. Stockton LW, Tsang ST. Microleakage of Class II posterior composite restorations with gingival margins placed entirely within dentin. J Can Dent Assoc. 2007;73(3): 255-255f.

24. Koubi S, Raskin A, Dejou J, About I, Tassery H, Camps J, et al. Effect of dual cure composite as dentin substitute on the marginal integrity of class II open-sandwich restorations. Oper Dent. MarApr 2010;35(2):165-71.

25. Garcia-Godoy F. Glass ionomer materials in Class II composite resin restorations: to etch or not to etch? Quintessence Int. 1988 Mar;19(3):241-2

26. Dietrich T, Kraemer M, Losche G, Wernecke K, Roulet J. Influence of dentin conditioning and contamination on the marginal integrity of sandwich Class II restorations. Oper Dent. Sep-Oct 2000;25(5):401-10

27. Kulczyk K, Sidhu S, McCabe J. Salivary contamination and bond strength of glass-ionomers to dentin. Oper Dent. 2005;30(6):676.

28. Dursun E, Attal J-P. Combination of a self-etching adhesive and a resin-modified glass ionomer: effect of water and saliva contamination on bond strength to dentin. J Adhes Dent. 2011 Oct;13(5):439-43.

29. Ludlow S, Farmer S, Donaldson M, Tantbirojn D, Versluis A. Microleakage of resin-modified glass ionomer restorations with selective enamel etching. Oper Dent. Jul-Aug 2014;39(4):E154-9.

30. Miller MR, Castellanos IR, Varcas MA, Denehy GE. Effect of restorative materials on microleakage of Class II composites. J Esthet Restor Dent. 1996;8(3):107-13.

31. Shafiei F, Akbarian S. Microleakage of nanofilled resin-modified glass-ionomer/silorane-or methacrylate-based composite sandwich Class II restoration: effect of simultaneous bonding. Oper Dent. Jan-Feb 2014;39(1):E22-30.

32. Czarnecka B, Kruszelnicki A, Kao A, Strykowska M, Nicholson JW. Adhesion of resin-modified glass-ionomer cements may affect the integrity of tooth structure in the open sandwich technique. Dent Mater. 2014;30(12):e301-e5.

33. Ebaya MM, Ali Al, Mahmoud SH. Evaluation of Marginal Adaptation and Microleakage of Three Glass lonomer-Based Class V Restorations: In Vitro Study. Eur J Dent. 2019 Oct;13(4):599-606.

34. Meral E, Baseren N. Shear bond strength and microleakage of novel glass-ionomer cements: An In vitro Study. Niger J Clin Pract. 2019;22(4):566.

35. Khoroushi M, Keshani F. A review of glass-ionomers: From conventional glass-ionomer to bioactive glass-ionomer. Dent Res J (Isfahan). 2013 Jul;10(4):411-20.

36. Lazaridou D, Belli R, Krämer N, Petschelt A, Lohbauer U. Dental materials for primary dentition: are they suitable for occlusal restorations? A two-body wear study. Eur Arch Paediatr Dent. 2015;16(2):165-72.

37. Gurgan S, Kutuk Z, Ergin E, Oztas S, Cakir F. Four-year randomized clinical trial to evaluate the clinical performance of a glass ionomer restorative system. Oper Dent. Mar-Apr 2015;40(2):134-43.

38. Moshaverinia M, Navas A, Jahedmanesh N, Shah KC, Moshaverin ia A, Ansari S. Comparative evaluation of the physical properties of a reinforced glass ionomer dental restorative material. J Prosthet Dent. 2019 Aug;122(2):154-159.

39. Ong JE-X, Yap A, Hong JY, Eweis AH, Yahya NA. Viscoelastic Properties of Contemporary Bulk-fill Restoratives: A Dynamic-mechanical Analysis. Oper Dent. May/Jun 2018;43(3):307-314. 